\title{
KEMAMPUAN KEPEMILIKAN INSTITUSIONAL MEMODERASI \\ PENGARUH EARNING POWER, LEVERAGE, DAN UKURAN PERUSAHAAN TERHADAP MANAJEMEN LABA
}

\author{
Raka \\ Institut Bisnis dan Informatika Kwik Kian Gie \\ rakajoe@ymail.com \\ Sugi Suhartono \\ Institut Bisnis dan Informatika Kwik Kian Gie \\ sugi.suhartono@kwikkiangie.ac.id
}

\begin{abstract}
This study aims to determine whether earnings power, leverage, and firm size affect earnings management and whether institutional ownership moderate the effect of earning power, leverage, and size of the company on earnings management. The theory underlying this research is agency theory and positive accounting theory. Based on both theories, the conflict of interest that occurs between the owner and the manager where each will tend to emphasize personal interests or certain parties. The sample in this study consists of 93 manufacturing companies listed on the Indonesia Stock Exchange for the period 2014-2016. Sampling was done by purposive sampling method. The data analysis technique used to test the hypothesis is Moderated Regression Analysis. The results of this study indicate earnings power, leverage, and firm size have a positive effect on earnings management. Institutional ownership weakens the effect of earning power on earnings management.
\end{abstract}

Keywords : Earning management, earning power, leverage, company size,

\section{PENDAHULUAN}

Laporan keuangan merupakan jendela perusahaan yang diharapkan dapat menyajikan informasi yang andal, valid dan relevan kepada pengguna informasi laporan keuangan. Pihak manajer merupakan pihak yang diberikan kepercayaan untuk mengelola sumber daya perusahaan. Setiap tindakan baik ataupun buruk yang diambil oleh manajer akan mempengaruhi kondisi perusahaan.

Dalam teori keagenan, terdapat pemisahan kepemilikan dan pengelolaan suatu perusahaan yang dapat menimbulkan masalah keagenan berupa ketidaksejajaran kepentingan antara pemilik dan manajer. Konflik ini juga tidak 
terlepas dari kecenderungan manajer untuk mencari keuntungan sendiri dengan mengorbankan kepentingan pihak lain karena walaupun manajer memperoleh kompensasi dari pekerjaannya, namun pada kenyataannya perubahan kemakmuran manajer sangat kecil dibandingkan perubahan kemakmuran pemilik.

Beberapa penelitian yang telah dilakukan untuk menemukan faktorfaktor yang dapat mempengaruh tindakan manajemen laba salah satunya seperti Surya et al. (2016) pernah melakukan penelitian untuk melihat pengaruh earning power terhadap earning management yang menghasilkan earning power berpengaruh positif terhadap manajemen laba. Pada penelitian Purnomo dan Puji Pratiwi (2009) menyatakan bahwa earning power berpengaruh terhadap praktik manajemen laba namun cenderung lemah. Selain itu penelitian yang dilakukan Alhavid menyatakan bahwa earning power tidak berpengaruh terhadap praktik manajemen laba.

Faktor lain yang mempengaruhi tindakan manajemen laba adalah leverage. Leverage merupakan suatu rasio yang digunakan untuk menilai seberapa besar aset perusahaan yang dibiayai dengan menggunakan hutang. Perusahaan yang lebih banyak asetnya dibiayai dengan hutang cenderung akan melakukan tindakan menaikkan jumlah laba yang diperoleh akibat tingginya beban bunga. Widyaningdyah (2001) dan Naftalia dan Marsono (2013) melakukan penelitian untuk melihat pengaruh leverage terhadap manajemen laba. Hasil penelitian berhasil memperoleh bukti bahwa leverage berpengaruh terhadap tindakan manajemen laba. Namun penelitian yang dilakukan Elfira (2014) menyatakan sebaliknya bahwa leverage tidak berpengaruh signifikan terhadap manajemen laba. Faktor ketiga yang dapat mempengaruhi tindakan manajemen laba yaitu ukuran perusahaan. Perusahaan yang tergolong besar pada umumnya akan lebih transparan dalam melakukan kegiatan operasionalnya. Sehingga dapat meminimalkan tindakan manajemen laba. Namun penelitian yang dilakukan oleh I Guna dan Arleen Herawaty (2010) menyatakan bahwa 
ukuran perusahaan tidak berpengaruh terhadap praktik manajemen laba. Namun berbeda dengan penelitian Ali et al. (2015) dan juga Handayani dan Agustono Dwi Rachadi (2009) yang menyatakan ukuran perusahaan berpengaruh terhadap manajemen laba.

Kepemilikan institusional umumnya dapat menjadi salah satu alat yang memonitor perusahaan dalam menjalankan kegiatan bisnisnya. Perusahaan dengan kepemilikan institusional yang besar mengindikasikan kemampuannya untuk memonitor pihak manajemen. Fungsi pemonitoran menjadi penting ketika kepemilikan institusional menjadi dasar dalam menilai tindakan manajemen laba. Berdasarkan penelitian Naftalia dan Marsono (2013) menyatakan bahwa kepemilikan institusional terbukti tidak memoderasi pengaruh leverage terhadap manajemen laba. Tetapi dalam penelitian-penelitian sebelumnya seperti penelitian Kamran dan Attaullah Shah (2014), Alves (2012), dan Yang et al. (2009) yang meneliti pengaruh kepemilikan institusional terhadap manajemen laba menghasilkan bahwa kepemilikan institusional memiliki hubungan negatif dengan manajemen laba.

Dengan berbagai penjelasan dan pertentangan-pertentangan dari hasil penelitian terdahulu mengenai manajemen laba maka rumusan masalah yang dibahas dalam penelitian ini adalah " Apakah earning power, leverage, dan ukuran perusahaan mempengaruhi manajemen laba?" serta "Apakah kepemilikan institusional memoderasi pengaruh earning power, leverage, dan ukuran perusahaan terhadap manajemen laba?"

Tujuan dari penelitian ini adalah untuk mengetahui pengaruh earning power, leverage, dan ukuran perusahaan terhadap manajemen laba serta untuk mengetahui pengaruh kepemilikan institusional dalam memoderasi pengaruh earning power, leverage, dan ukuran perusahaan terhadap manajemen laba.

\section{TELAAH LITERATUR}

\section{Teori Keagenan (Agency Theory)}

Teori keagenan didasarkan pada berbagai aspek dan implikasi 
hubungan keagenan, yaitu hubungan antara principal dan agent. Menurut Jensen dan Meckling (1976: 308), teori keagenan adalah sebuah kontrak antara pihak principal dengan pihak agent, dimana pihak agent memiliki tanggung jawab atas kuasa yang diberikan oleh pihak principal dalam pengambilan keputusan.

Eisenhardt (1989) menyatakan bahwa teori agensi menggunakan tiga asumsi sifat manusia yaitu: (1) manusia pada umumnya mementingan diri sendiri (self interest), (2) manusia memiliki daya pikir terbatas mengenai persepsi masa mendatang (bounded rationality), dan (3) manusia selalu menghindari resiko (risk averse). Berdasarkan asumsi sifat dasar manusia tersebut, manajer sebagai manusia akan bertindak opportunistic, yaitu mengutamakan kepentingan pribadinya. Konflik kepentingan semakin meningkat terutama karena principal tidak dapat memonitor akitvitas CEO sehari-hari untuk memastikan bahwa CEO bekerja sesuai dengan keinginan pemegang saham. Principal tidak memiliki informasi mengenai perusahaan secara keseluruhan sehingga mengakibatkan ketidakseimbangan informasi yang dimiliki oleh principal dan agent.

Ketidakseimbangan informasi inilah yang disebut dengan asimetri informasi. Asimetri informasi dan konflik kepentingan yang terjadi antara principal dan agent mendorong agent untuk menyajikan informasi yang tidak sebenarnya kepada principal. Hal tersebut memacu agent untuk memikirkan bagaimana angka akuntansi yang akan disajikan dapat menjadi sarana untuk memaksimalkan kepentingannya.

\section{Teori Akuntansi Positif (Positive} Accounting Theory)

Teori akuntansi positif adalah teori akuntansi yang mengidentifikasi dan menganalisis berbagai bentuk praktik manajemen laba yang dilakukan manajer perusahaan. Teori ini secara khusus berusaha mengungkapkan pengaruh dari variabel-variabel ekonomi terhadap motivasi manajer untuk memilih suatu metode akuntansi. Teori akuntansi positif mengasumsikan manajer selalu berpikir rasional dan akan memilih 
kebijakan akuntansi yang dapat menguntungkan kepentingan mereka. Dengan demikian fleksibilitas yang diberikan oleh teori ini dalam memilih kebijakan akuntansi akan mendukung perilaku oportunistik para manajer. Tipe hipotesis teori akuntansi positif yang dapat menjadikan dasar pemahaman tindakan manajemen laba yang dirumuskan oleh Watts dan Zimmerman (1986: 208-236) adalah sebagai berikut:

(1) Bonus Plan Hypothesis menyatakan "managers of firms with bonus plans are more likely to use accounting methods that increase current period reported income". Dalam hipotesis tersebut, perjanjian bisnis manajer dengan pihak lain merupakan salah satu faktor yang mempengaruhi tingkat manajemen laba yang dilakukan perusahaan. Variabel yang berkaitan dengan perjanjian bisnis itu, yaitu bonus atau kompensasi manajerial. Dalam bonus atau kompensasi manajerial, pemilik perusahaan berjanji bahwa manajer akan menerima sejumlah bonus jika kinerja perusahaan mencapai jumlah tertentu. Janji bonus inilah yang merupakan alasan bagi manajer untuk mengelola dan mengatur labanya pada tingkat tertentu sesuai dengan yang disyaratkan agar dapat menerima bonus.

(2) Debt (Equity) Hypothesis menyatakan "the larger the firms debt to equity ratio, the more likely managers use accounting methods that increase income". Dalam hipotesis tersebut, perusahaan yang memiliki rasio utang terhadap modal yang cukup tinggi akan berakibat menimbulkan kesulitan dalam memperoleh dana tambahan dari pihak kreditor dan bahkan perusahaan dapat terancam melanggar perjanjian utang. Pelanggaran perjanjian utang akan membuat tambahan biaya pada perusahaan. Dan hal itu juga akan membuat reputasi mereka buruk di pandangan pihak eksternal. Maka dari itu untuk menjaga reputasi perusahaan di pandangan pihak eksternal manajer perusahaan 
akan cenderung memilih metode akuntansi yang memiliki dampak meningkatkan laba.

(3) Political Cost Hypothesis yang menyatakan bahwa "Larger firms rather than small firms are more likely to use accounting choices that reduce reported profits". Dalam hipotesis tersebut adalah tentang masalah pelanggaran regulasi pemerintah. Besar kecilnya pajak yang akan ditarik oleh pemerintah sangat tergantung pada besar kecilnya laba yang dicapai perusahaan. Kondisi inilah yang akan merangsang manajer untuk mengelola dan mengatur labanya dalam jumlah tertentu agar pajak yang harus dibayarkannya menjadi tidak terlalu tinggi, karena manajer tentu tidak ingin kewajiban yang harus diselesaikannya terlalu membebaninya.

\section{Manajemen Laba}

Manajemen laba adalah upaya yang digunakan manajer untuk merekayasa informasi-informasi dalam laporan keuangan dengan mempermainkan metode dan prosedur akuntansi yang digunakan perusahaan untuk mengelabui pihakpihak yang ingin mengetahui kinerja dan kondisi perusahaan. Manajemen laba berkaitandengan teknik memilih metode akuntansi yang paling menguntungkan sehingga tujuan laba yang diinginkan tercapai, dimana disini manajer menggunakan komponen discretionary accruals dalam menentukan besaran laba. Pola-pola manajemen laba yang di lakukan manajer menurut Scott (2015: 447) adalah sebagai berikut:

(1) Taking a Bath

Pola ini dilakukan selama keadaan buruk yang tidak menguntungkan yang tidak dapat dihindari atau masa restrukturisasi seperti pergantian CEO baru. Perusahaan melakukan taking a bath dengan cara menjadikan laba perusahaan pada periode berjalan menjadi sangat ekstrim rendah. Jika perusahaan mengalami kerugian, maka kerugian akan dilimpahkan pada manajer lama dengan harapan manajer yang baru dapat menghasilkan laba pada periode mendatang.

(2) Income Minimization 
Pola ini dilakukan saat profitabilitas perusahaan sangat tinggi dengan tujuan agar tidak mendapat perhatian secara politis selama masa periode peningkatan laba. Income minimization biasa dilakukan saat perusahaan sedang mendapat sorotan publik selama masa keuntungan sangat tinggi atau untuk menghindari pajak.

(3) Income Maximization

Pola ini dilakukan untuk memperoleh bonus yang lebih besar dengan cara untuk melaporkan net income yang tinggi. Tindakan ini dilakukan pada saat laba perusahaan menurun. Demikian pula perusahaan yang mendekati suatu pelanggaran perjanjian hutang, manajer perusahaan akan cenderung memaksimalkan laba.

(4) Pemerataan Laba (Income Smoothing)

Pola ini dilakukan dengan cara meratakan laba yang dilaporkan untuk tujuan pelaporan eksternal, terutama bagi investor dikarenakan investor cenderung menyukai laba yang relatif stabil.

Motivasi-motivasi perusahaan untuk melakukan manajemen laba menurut Scott (2015: 448-457) adalah sebagai berikut:

(1) Bonus Scheme (Skema Bonus)

Dalam skema bonus dikenal dua istilah penting yaitu bogey dan cap. Bogey merupakan batas bawah yang ditentukan untuk memperoleh bonus, sementara cap adalah batas atas yang ditentukan untuk memperoleh bonus lebih.

(2) Other Contracting Motivations (Motivasi Kontrak Lain)

Kontrak hutang yang biasanya bergantung pada variabelvariabel akuntansi muncul dari moral hazard yang terjadi antara manajer dengan pemberi pinjaman. Untuk mengatasi masalah ini, kontrak hutang jangka panjang selalu membuat perjanjian untuk mencegah manajer bertindak berlawanan dengan kepentingan pemberi pinjaman, seperti membagi dividen yang berlebihan, menambah pinjaman, atau 
membiarkan modal kerja mendeteksi manajemen laba. Modelperusahaan turun sampai kepada tingkat tertentu.

(3) To Meet Investors' Earnings Expectations (Untuk Memenuhi Laba yang Diharapkan Investor) Jika tidak dapat mencapai laba yang diharapkan investor, maka pasar menilai manajer perusahaan tidak mampu mengelola perusahaan dengan baik. Karena itu manajer perusahaan terdorong untuk melakukan manajemen laba agar laba perusahaan yang dilaporkan selalu sesuai dengan harapan investor.

(4) Stock Offerings (Penawaran Saham)

Informasi keuangan yang terdapat dalam prospektus menjadi sumber informasi yang bisa membantu para calon investor mengambil keputusan. Untuk menarik perhatian para investor, perusahaan akan memaksimalisasi laba perusahaan dan melakukan pemerataan laba.

Menurut Sulistyanto (2014: 216-232)

\section{Pengaruh Earning Power terhadap Manajemen Laba}

Earning power adalah kemampuan untuk mengetahui efisiensi perusahaan dengan melihat besar kecilnya dalam menghasilkan laba. Earning power dapat diukur dengan return on asset (ROA). Semakin tingginya jumlah laba yang dapat diperoleh menyebabkan manajer perusahaan cenderung akan melakukan penurunan jumlah laba yang diperoleh dengan tujuan untuk menghindari tuntutan diperolehnya jumlah laba yang lebih tinggi di masa datang. Dengan demikian semakin tingginya jumlah laba menyebabkan manajer cenderung melakukan praktik manajemen laba. Sebaliknya, jika semakin rendah jumlah laba maka manajer akan model empiris bertujuan untuk 
cenderung tidak akan melakukan praktik manajemen laba.

Hal ini didukung oleh penelitian Surya et al. (2016) dan juga Purnomo dan Puji Pratiwi (2009) yang menyatakan bahwa pengaruh earning power terhadap manajemen laba mempunyai hubungan yang erat serta searah atau positif yang berarti apabila terjadi kenaikan pada earning power perusahaan akan diikuti dengan kenaikan nilai discretionary accrual, begitu pula sebaliknya jika terjadi penurunan earning power akan terjadi penurunan discretionary accrual pula.

\section{Ha1 : Earning power berpengaruh positif terhadap manajemen laba}

\section{Pengaruh Leverage terhadap} Manajemen Laba

Leverage adalah hasil penggunaan biaya tetap dari aset atau penggunaan pembiayaan untuk meningkatkan tingkat pengembalian bagi pemegang saham. Leverage dapat diukur dengan Debt to Equity Ratio. Rasio ini berguna untuk mengetahui besarnya perbandingan antara jumlah dana yang disediakan oleh kreditor dengan jumlah dana yang berasal dari pemilik perusahaan. Dengan kata lain rasio ini berfungsi untuk mengetahui berapa bagian dari setiap rupiah modal yang dijadikan sebagai jaminan utang. Dengan demikian semakin tingginya Debt to Equity Ratio maka risiko kreditor berupa ketidakmampuan perusahaan untuk membayar kewajibannya sehingga manajer akan cenderung memutuskan untuk melakukan manajemen laba agar tidak terjadi pelanggaran perjanjian hutang yang dapat menimbulkan biaya lebih. Sehingga dapat disimpulkan bahwa semakin tingginya debt to equity ratio maka manajer akan cenderung melakukan manajemen laba.

Hal ini didukung oleh penelitianpenelitian terdahulu, Safitri (2014) dan juga Naftalia dan Marsono (2013) yang menyatakan bahwa leverage berpengaruh signifikan terhadap pelaksanaan manajemen laba perusahaan.

\section{Ha2 : Leverage berpengaruh positif terhadap manajemen laba}


Pengaruh Ukuran Perusahaan terhadap Manajemen Laba

Ukuran perusahaan merupakan salah satu faktor yang mempengaruhi praktik manajemen laba. Ukuran perusahaan dapat diukur dengan logaritma natural dari total aset perusahaan. Handayani dan Agustono Dwi Rachadi (2009) menemukan bahwa ukuran perusahaan berpengaruh negative terhadap manajemen laba. Perusahaan besar kurang memiliki motivasi dalam melakukan praktik manajemen laba. Hal ini dikarenakan pemegang saham dan pihak-pihak berkepentingan di perusahaan besar dianggap lebih kritis dibandingkan dengan perusahaan kecil. Semakin besar perusahaan akan cenderung untuk menurunkan praktik manajemen laba, karena perusahaan besar secara politis lebih mendapat perhatian dari institusi pemerintahan dibandingkan dengan perusahaan kecil.

Ha3 : Ukuran perusahaan
berpengaruh negatif terhadap
manajemen laba

Pengaruh Kepemilikan

Institusional dalam memoderasi hubungan antara Earning Power terhadap Manajemen Laba

Manajer cenderung melakukan praktik manajemen laba jika jumlah laba semakin tinggi untuk menghindari tuntutan jumlah laba yang lebih tinggi di masa mendatang. Dalam penelitian yang dilakukan oleh Yang et al. (2009) membuktikan bahwa kepemilikan institusional berpengaruh negatif terhadap manajemen laba. Dengan adanya pihak institusi maka pengendalian dan pengawasan tindakan manajer semakin ketat. Dengan kata lain manajer semakin sulit untuk melakukan praktik manajemen laba. Sehingga semakin banyaknya pihak institusi akan memperlemah pengaruh earning power terhadap manajemen laba.

\section{Ha4 : Kepemilikan Institusional memperlemah hubungan earning power terhadap manajemen laba}

\begin{tabular}{|c|c|c|}
\hline Pengaruh & & Kepemilikan \\
\hline Institusional & dalam & memoderasi \\
\hline hubungan & antara & Leverage \\
\hline
\end{tabular}


Jika tingkat leverage perusahaan tinggi, maka manajer cenderung akan melakukan praktik manajemen laba. Dengan adanya pihak institusi maka pengendalian dan pengawasan tindakan manajer semakin ketat. Sehingga jika pada tingkat leverage tinggi dan manajer ingin melakukan praktik manajemen laba agar tidak terjadi risiko penambahan biaya, pihak institusi berperan dalam mengawasi tindakan-tindakan manajer. Dengan kata lain manajer akan lebih sulit untuk melakukan praktik manajemen laba. Sehingga semakin banyaknya pihak institusi akan memperlemah pengaruh leverage terhadap manajemen laba.

\section{Ha5 : Kepemilikan Institusional memperlemah hubungan leverage terhadap manajemen laba}

\section{Pengaruh}

Kepemilikan

Institusional dalam memoderasi hubungan antara Ukuran

Perusahaan terhadap Manajemen

\section{Laba}

Diketahui dalam penelitian Handayani dan Agustono Dwi Rachadi (2009) telah menyatakan bahwa perusahaan besar kurang memiliki motivasi dalam melakukan praktik manajemen laba. Sehingga dengan adanya pihak institusi sebagai pengendali dan pengawasan tindakan manajer dalam mengambil keputusan, dengan kata lain adanya pihak institusi akan lebih mengurangi motivasi manajer dalam mengambil keputusan untuk melakukan praktik manajemen laba. Sehingga dengan semakin banyaknya pihak institusi yang ada dalam suatu perusahaan maka akan memperkuat pengaruh ukuran perusahaan terhadap manajemen laba.

\section{Ha6 : Kepemilikan Institusional memperkuat hubungan ukuran perusahaan terhadap manajemen} laba

\section{METODOLOGI PENELITIAN}

\section{Teknik Pengumpulan Data}

Data yang digunakan dalam penelitian ini adalah data sekunder berupa laporan keuangan tahunan yang mencangkup laba bersih, aliran kas aktivitas operasi, total aktiva, pendapatan, aktiva tetap, piutang, total kewajiban, jumlah saham institusional, dan jumlah saham beredar pada perusahaan-perusahaan 
manufaktur yang terdaftar di Bursa Efek Indonesia.

\section{Variabel Penelitian}

Manajemen Laba

\section{Objek Penelitian}

Manajemen laba adalah upaya yang

Objek yang digunakan dalam digunakan manajer untuk penelitian ini adalah laporan merekayasa informasi-informasi keuangan auditan perusahaanperusahaan go public yang termasuk dalam kategori perusahaan manufaktur, yang terdaftar di Bursa Efek Indonesia (BEI) dan Indonesia Capital Market Directory (ICMD). Periode laporan keuangan auditan perusahaan digunakan adalah 3 tahun yakni tahun 2014, 2015, dan 2016. dalam laporan keuangan dengan mempermainkan metode dan prosedur akuntansi yang digunakan perusahaan untuk mengelabui pihakpihak yang ingin mengetahui kinerja dan kondisi perusahaan. Pengukuran manajemen laba akan menggunakan Model Jones Dimodifikasi dengan langkah-langkah sebagai berikut:

1. Menghitung total accrual dengan persamaan:

$$
\mathrm{TACC}_{\mathrm{it}}=\mathrm{N}_{\mathrm{it}}-\mathrm{CFO}_{\mathrm{it}}
$$

2. Menghitung nilai accrual dengan persamaan regresi linier sederhana dengan persamaan:

$$
\frac{\mathrm{TACC}_{\mathrm{it}}}{\mathrm{TA}_{\mathrm{it}-1}}=\alpha_{1}\left(\frac{1}{\mathrm{TA}_{\mathrm{it}-1}}\right)+\alpha_{2}\left(\frac{\Delta \mathrm{REV}_{\mathrm{it}}}{\mathrm{TA}_{\mathrm{it}-1}}\right)+\alpha_{3}\left(\frac{\mathrm{PPE}_{\mathrm{it}}}{\mathrm{TA}_{\mathrm{it}-1}}\right)+\varepsilon
$$

3. Dengan menggunakan koefisien regresi diatas, nilai non discretionary accrual (NDA) dapat dihitung dengan rumus:

$$
\mathrm{NDACC}_{\mathrm{it}}=\alpha_{1}\left(\frac{1}{\mathrm{TA}_{\mathrm{it}-1}}\right)+\alpha_{2}\left(\frac{\Delta \mathrm{REV}_{\mathrm{it}}}{\mathrm{TA}_{\mathrm{it}-1}}-\frac{\Delta \mathrm{REC}_{\mathrm{it}}}{\mathrm{TA}_{\mathrm{it}-1}}\right)+\alpha_{3}\left(\frac{\mathrm{PPE}_{\mathrm{it}}}{\mathrm{TA}_{\mathrm{it}-1}}\right)+\varepsilon
$$


4. Menghitung nilai discretionary accrual dengan persamaan:

$$
\mathrm{DACC}_{\mathrm{it}}=\frac{\mathrm{TACC}_{\mathrm{it}}}{\mathrm{TA}_{\mathrm{it}-1}}-\mathrm{NDACC}_{\mathrm{it}}
$$

Di mana:

DACC $_{\text {it }}=$ Discretionary Accruals perusahaan i pada periode ke $\mathrm{t}$

$\mathrm{NDACC}_{\mathrm{it}}=$ Non Discretionary Accruals perusahaan i pada periode ke $\mathrm{t}$

$\mathrm{TACC}_{\mathrm{it}}=$ Total Akrual perusahaan i pada periode ke $\mathrm{t}$

$\mathrm{N}_{\text {it }} \quad=$ Laba bersih perusahaan $\mathrm{i}$ pada periode ke $\mathrm{t}$

$\mathrm{CFO}_{\text {it }}=$ Aliran kas dari aktivitas operasi perusahaan i pada periode ke $\mathrm{t}$

$\mathrm{TA}_{\mathrm{it}-1}=$ Total aktiva perusahaan $\mathrm{i}$ pada periode ke $\mathrm{t}-1$

$\Delta \mathrm{REV}_{\mathrm{it}}=$ Perubahan pendapatan perusahaan i pada periode ke $\mathrm{t}$

$\mathrm{PPE}_{\mathrm{it}}=$ Aktiva tetap perusahaan $\mathrm{i}$ pada periode ke $\mathrm{t}$

$\triangle \mathrm{REC}_{\mathrm{it}}=$ Perubahan piutang perusahaan i pada periode ke $\mathrm{t}$

$\mathrm{E}=$ error term perusahaan $\mathrm{i}$ pada periode $\mathrm{ke} \mathrm{t}$

Earning Power

Earning power adalah kemampuan untuk mengetahui efisiensi perusahaan dengan melihat besar kecilnya dalam menghasilkan laba. Pengukuran earning power akan

menggunakan return on asset (ROA). Skala yang digunakan dalam variabel earning power adalah skala rasio. Earning power dapat dinilai dengan menggunakan rumus sebagai berikut:

$$
\mathrm{ROA}=\frac{\text { Laba Bersih }}{\text { Total Aset }}
$$

Leverage

Leverage adalah hasil penggnaan biaya tetap dari aset atau penggunaan pembiayaan untuk meningkatkan tingkat pengembalian bagi pemegang saham. Penelitian ini menggunakan debt to equity ratio (DER) sebagai proksi dari leverage perusahaan. Skala yang digunakan dalam variabel leverage adalah skala rasio. Leverage dapat dinilai dengan menggunakan rumus sebagai berikut: 


$$
\mathrm{DER}=\frac{\text { Total Liabilities }}{\text { Common Stock Equity }}
$$

Ukuran Perusahaan

Ukuran perusahaan adalah salah satu faktor yang menentukan bagi investor dalam memutuskan untuk berinvestasi. Pengukuran perusahaan dalam penelitian ini menggunakan logaritma natural dari total aset suatu perusahaan. Skala yang digunakan variabel ukuran perusahaan adalah skala rasio. Dengan demikian ukuran perusahaan akan dinilai sebagai berikut:

$$
\text { Size }=\ln (\text { Total Asset })
$$

Kepemilikan Institusional

Kepemilikan Institusional adalah variabel moderating dalam penelitian ini. Donald R. Copper dan Pamela S Schindler (2017: 65-66) menyatakan variabel moderator atau interaksi merupakan variabel bebas kedua yang dilibatkan karena diyakini

$$
\text { Kepemilikan Institusional }=\frac{\text { Jumlah Saham Institusional }}{\text { Jumlah Saham Beredar }}
$$

\section{HASIL \& ANALISIS}

Gambaran Umum Objek

\section{Penelitian}

Penelitian ini menggunakan data dari laporan keuangan auditan untuk seluruh perusahaan yang terdaftar di Bursa Efek Indonesia (BEI). Sampel penelitian ini adalah sebanyak 93 memiliki kontribusi yang signifikan atau memiliki kesatuan pengaruh dalam hubungan variabel independen dan variabel dependen yang asli. Variabel kepemilikan institusional diukur dengan rumus sebagai berikut:

perusahaan pertahunnya dalam industri manufaktur dengan periode penelitian tahun 2014 sampai tahun 2016 sehingga diperoleh total sampel sebanyak 279 perusahaan. Proses pengambilan sampel pada penelitian ini adalah sebagai berikut: 
Tabel 1. Proses Pengambilan Sampel

\begin{tabular}{|c|c|c|c|}
\hline No. & Kriteria & Jumlah & Akumulasi \\
\hline 1. & $\begin{array}{l}\text { Total perusahaan manufaktur yang terdaftar di BEI } \\
\text { tahun 2014-2016 }\end{array}$ & & 430 \\
\hline 2. & $\begin{array}{l}\text { Total perusahaan manufaktur yang baru listing } \\
\text { (IPO) selama periode pengujian }\end{array}$ & (9) & 421 \\
\hline 3. & $\begin{array}{l}\text { Total perusahaan manufaktur yang di delisting } \\
\text { selama periode pengujian }\end{array}$ & (4) & 417 \\
\hline 4. & $\begin{array}{l}\text { Total perusahaan manufaktur yang datanya tidak } \\
\text { lengkap }\end{array}$ & (129) & 288 \\
\hline 5. & $\begin{array}{l}\text { Total perusahaan manufaktur yang tidak } \\
\text { menggunakan mata uang Rupiah }\end{array}$ & (9) & 279 \\
\hline $\begin{array}{l}\text { Jum } \\
\text { sam }\end{array}$ & $\begin{array}{l}\text { h perusahaan manufaktur yang terpilih sebagai } \\
\text { l ( } 3 \text { tahun) }\end{array}$ & 93 & 279 \\
\hline
\end{tabular}

\section{Analisis Deskriptif}

Berdasarkan hasil uji statistik deskriptif diperoleh sebanyak 279 data yang berasal dari 93 sample perusahaan mulai tahun 2014 sampai dengan tahun 2016. Hasil uji statistik deskriptif dapat dilihat pada tabel 2 berikut ini.

Tabel 2. Statistik Deskriptif

\begin{tabular}{ccrrrr}
\hline & N & Minimum & Maximum & \multicolumn{1}{c}{ Mean } & Std. Dev \\
\hline ML & 279 & $-0,7600$ & 1,3800 & $-0,0001$ & 0,1875 \\
EP & 279 & $-0,5484$ & 1,3392 & 0,0661 & 0,1638 \\
LEV & 279 & $-8,3400$ & 22,4600 & 1,1548 & 2,2614 \\
SIZE & 279 & 22,7577 & 33,1988 & 28,2363 & 1,6445 \\
KI & 279 & 1,9600 & 99,7700 & 71,5087 & 17,7268 \\
Valid N (listwise) & 279 & & & & \\
\hline
\end{tabular}

Tabel 2 menunjukkan statistik deskriptif masing-masing variabel penelitian. Berdasarkan Tabel 4.2, hasil analisis dengan menggunakan statistik deskriptif dengan SPSS dapat diketahui bahwa jumlah data yang digunakan dalam pengujian ini berjumlah 279 data dan : a. Variabel manajemen laba (ML) menunjukkan nilai minimum sebesar -0,76; nilai maksimum sebesar 1,38; nilai rata-rata (mean) sebesar -0,000143; dan nilai standar deviasi sebesar 0,187 .

b. Variabel earning power (EP) menunjukkan minimum sebesar 
-0,548; nilai maksimum sebesar 1,339; nilai rata-rata (mean) sebesar 0,066 dan nilai standar deviasi sebesar 0,164 .

c. Variabel leverage (LEV) menunjukkan nilai minimum sebesar -8,34; nilai maksimum sebesar 22,46; nilai rata-rata (mean) sebesar 1,155 dan nilai standar deviasi sebesar 2,261.

d. Variabel ukuran perusahaan (SIZE) menunjukkan nilai minimum sebesar 22,758; nilai maksimum sebesar 33,199; nilai rata-rata (mean) sebesar 22,236 dan nilai standar deviasi sebesar 1,645 .

e. Variabel kepemilikan institusional (KI) menunjukkan nilai minimum sebesar 1,96 ; nilai maksimum sebesar 99,77; nilai rata-rata (mean) sebesar

\section{Hasil Penelitian}

\section{a. Uji Kesamaan Koefisien}

Pengujian ini dilakukan untuk melihat apakah pooling data (penggabungan antara data cross sectional dan time series) dapat dilakukan. Jumlah periode penelitian sebanyak tiga tahun sehingga membutuhkan dua dummy tahun (DT1 dan DT2). DT1 bernilai "1" jika data merupakan periode 2016, dan "0" jika data selain tahun 2016. DT2 bernilai "1" jika data merupakan periode 2015 dan "0" jika data selain tahun 2015. Kemudian seluruh variable independen dikalikan dengan dummy tahun tersebut. Hasil uji kesamaan koefisien dapat dilihat dari table 3 berikut ini:

71,509 dan nilai standar deviasi sebesar 17,727 .

Tabel 3. Hasil Uji Kesamaan Koefisien

\begin{tabular}{ll}
\hline \multicolumn{1}{c}{ Variabel } & Sig. \\
\hline EP_DT1 & 0,541 \\
LEV_DT1 & 0,481 \\
SIZE_DT1 & 0,880 \\
EP_KI_DT1 & 0,707 \\
LEV_KI_DT1 & 0,553 \\
SIZE_KI_DT1 & 0,880 \\
EP_DT2 & 0,895 \\
\hline
\end{tabular}


Kemampuan Kepemilikan Institusional Memoderasi Pengaruh Earning Power, Leverage, dan Ukuran Perusahaan Terhadap Manajemen Laba

\begin{tabular}{ll}
\hline \multicolumn{1}{c}{ Variabel } & Sig. \\
\hline LEV_DT2 & 0,967 \\
SIZE_DT2 & 0,742 \\
EP_KI_DT2 & 0,783 \\
LEV_KI_DT2 & 0,904 \\
SIZE_KI_DT2 & 0,331 \\
\hline
\end{tabular}

b. Uji Asumsi Klasik

(1) Uji Normalitas

Pengujian ini menggunakan

grafik histogram dan grafik normal probability plot yang dapat dilihat dari gambar 1 dan 2 berikut.

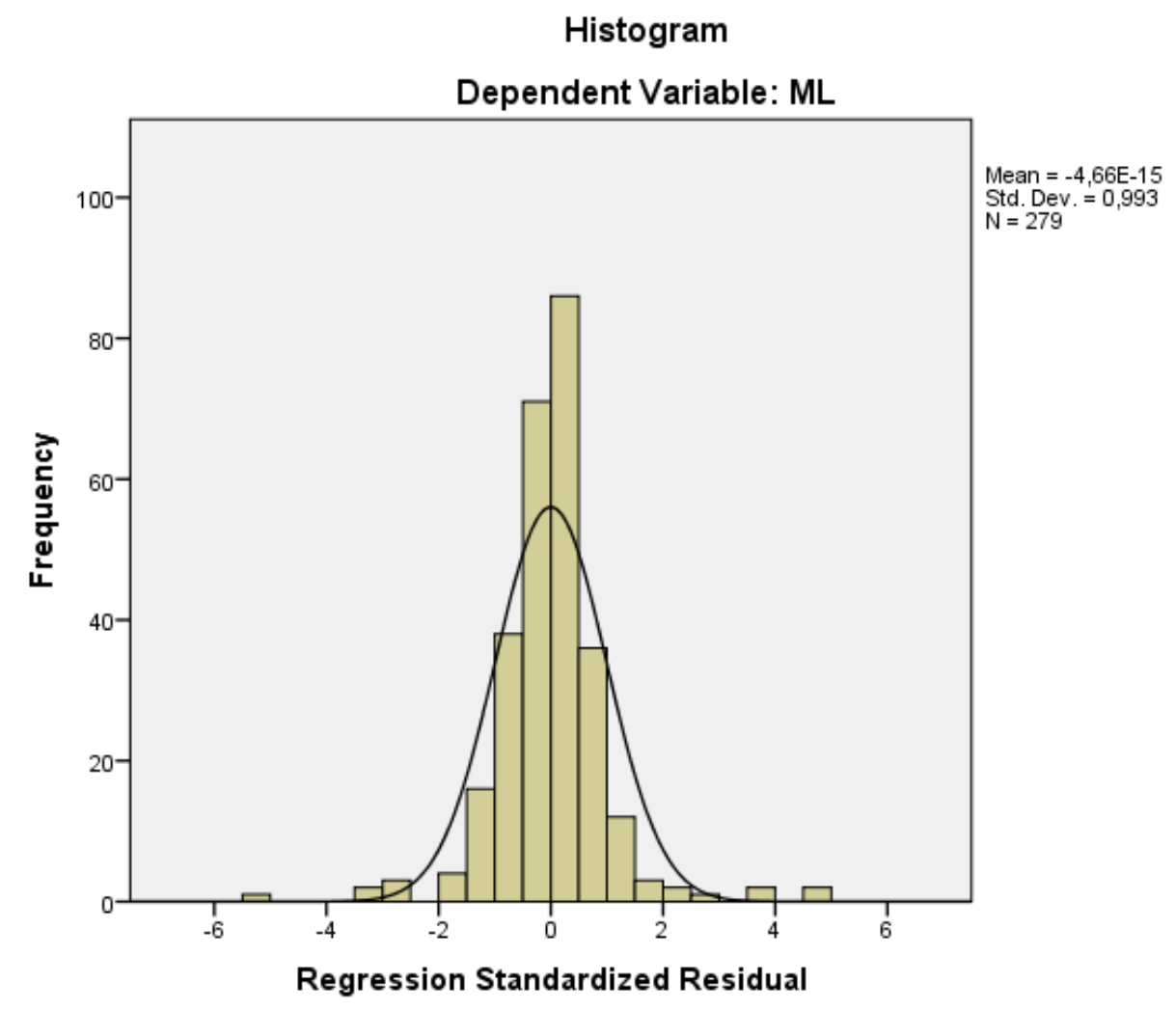

Gambar 1. Grafik Histogram 


\section{Normal P-P Plot of Regression Standardized Residual}

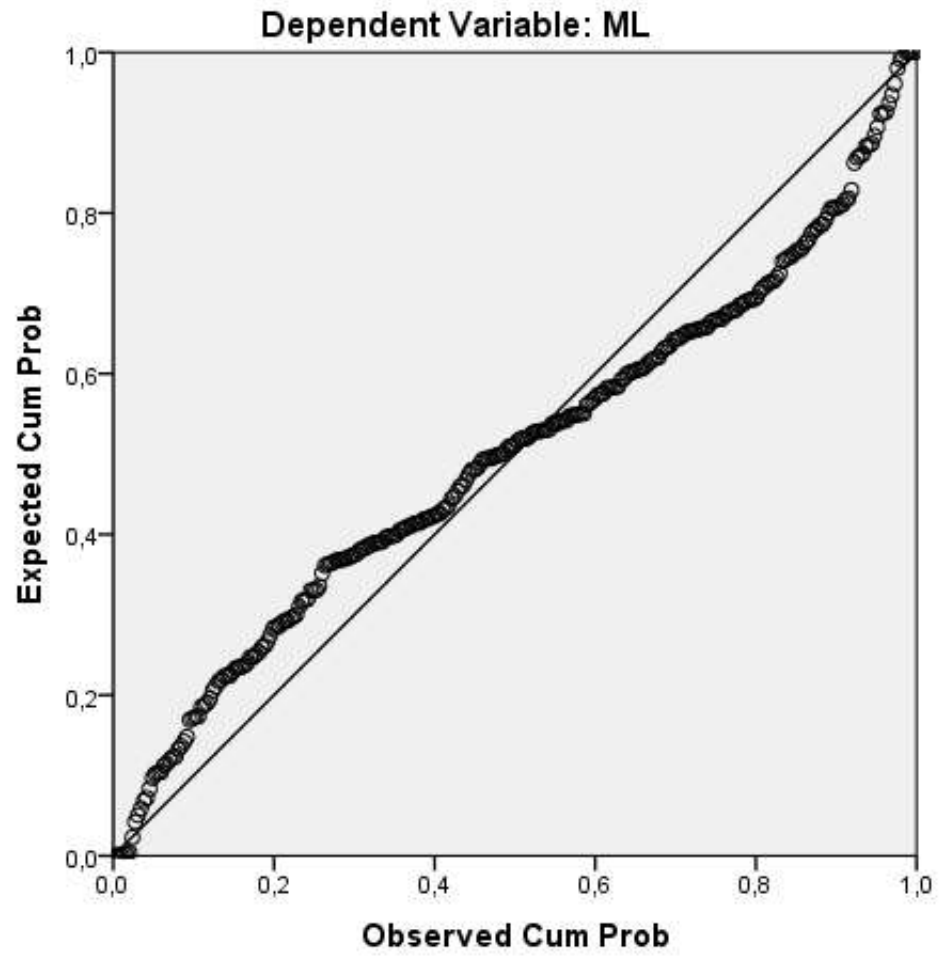

Gambar 2. Grafik Normal Probability Plot

Berdasarkan hasil tersebut

pola distribusi yang tidak mlenceng ke arah kiri maupun kanan pada grafik histogram dan pola titiktitik mengikuti dan mendekati garis diagonalnya pada grafik normal probability plot menandakan bahwa data dalam model sudah berdistribusi dengan normal. Namun menurut Ghozali (2016: 32) grafik kadang-kadang dapat menyesatkan karena kelihatan distribusinya normal tetapi secara statistik sebenarnya tidak normal. Namun data dalam model penelitian ini dapat dikatakan memiliki distribusi normal, karena jumlah sampel yang dimiliki dalam pengujian ini sudah jauh lebih besar dari 30 (Bowerman et al. , 2014: 278) yaitu sebesar 279.

(2) Uji Heterokedastisitas 
Pengujian ini menggunakan

uji park untuk melihat apakah terjadi heterokedastisitas. Hasil pengujian untuk variabel EP, LEV, SIZE, EP_KI, LEV_KI, dan SIZE_KI semua nilai signifikansi $\geq 0,05 \quad$ sehingga dapat disimpulkan bahwa dalam penelitian ini tidak terjadi heteroskedastisitas. Hasil uji park dapat dilihat pada tabel 4 berikut.

\section{Tabel 4.Uji Heteroskedastisitas}

\begin{tabular}{lc}
\hline \multicolumn{1}{c}{ Model } & Sig. \\
\hline EP & 0,126 \\
LEV & 0,564 \\
SIZE & 0,227 \\
EP_KI & 0,411 \\
LEV_KI & 0,607 \\
SIZE_KI & 0,396 \\
\hline
\end{tabular}

(3) Uji Multikolinieritas

Uji multikolinieritas dalam penelitian ini menggunakan variance inflation factor (VIF) dan tolerance. Hasil pengujian untuk variabel earning power, leverage, ukuran perusahaan dan kepemilikan institusional diperoleh nilai $\mathrm{VIF} \leq 10$ dan hasil uji variabel diperoleh nilai tolerance $\geq 0,1$ sehingga dapat disimpulkan bahwa penelitian ini bebas dari multikolinieritas. Hasil uji multikolonieritas dapat dilihat pada tabel 5 berikut.

Tabel 5. Uji Multikolinieritas

\begin{tabular}{lrr}
\hline \multirow{2}{*}{ Model } & \multicolumn{2}{c}{ Collinearity Statistiks } \\
\cline { 2 - 3 } & Tolerance & \multicolumn{1}{c}{ VIF } \\
\hline EP & 0,969 & 1,032 \\
LEV & 0,996 & 1,004 \\
SIZE & 0,963 & 1,039 \\
KI & 0,980 & 1,021 \\
\hline
\end{tabular}


(4) Uji Autokorelasi

Pengujian autokorelasi dalam penelitian ini menggunakan pengujian Durbin-Watson (DW test). Hasil pengujian autokorelasi diperoleh nilai hitung durbin-watson sebesar 2,068 dan dengan tabel durbin-watson diperoleh nilai dU sebesar 1,84029 dan nilai 4-dU sebesar 2,15971. Sehingga dapat disimpulkan bahwa nilai durbin-watson terletak diantara batas atas (dU) dan 4 - dU, maka koefisien korelasi sama dengan 0 , yang berarti tidak terdapat autokorelasi pada penelitian ini. Hasil uji autokorelasi dapat dilihat pada tabel 4.6 berikut.

Tabel 6. Uji Autokorelasi

\begin{tabular}{cccc}
\hline Durbin-Watson & N & k & dU \\
\hline 2,068 & 279 & 6 & 1,84029 \\
\hline
\end{tabular}

\section{Uji Hipotesis}

(1) Analisis Regresi Linear Berganda

Tabel 7. Model 1 - Regresi Linear Berganda

\begin{tabular}{lccc}
\hline & $\begin{array}{c}\text { Unstandardized } \\
\text { Coefficients }\end{array}$ & & \\
\multicolumn{1}{c}{ Model } & B & T & $\begin{array}{c}\text { Sig. } \\
\text { (One tailed) }\end{array}$ \\
\hline (Constant) & $-1,191$ & $-7,464$ & 0,000 \\
EP & 0,461 & 8,101 & 0,000 \\
LEV & 0,008 & 1,969 & 0,049 \\
SIZE & 0,041 & 7,207 & 0,000 \\
R Square $\left(\mathrm{R}^{2}\right)$ & & & 0,338 \\
F $_{\text {hitung }}$ & & & 46,897 \\
Sig. F & & & $0,000^{\mathrm{b}}$ \\
\hline
\end{tabular}

Dependent Variable: ML

Berdasarkan tabel 4.7 dapat menghasilkan model sebagai berikut:

$\mathrm{ML}=-1,191+0,461 \mathrm{EP}+0,008 \mathrm{LEV}+0,041 \mathrm{SIZE}$ 
Hasil analisis regresi berganda pada tabel 4.7 menunjukkan bahwa:

a. Earning power berpengaruh positif terhadap manajemen laba

b. Leverage berpengaruh positif terhadap manajemen laba

c. Ukuran perusahaan berpengaruh positif terhadap manajemen laba

(2) Analisis Regresi dengan Moderated Regression Analysis (MRA)

Tabel 8. Model 2 - Moderated Regression Analysis (MRA)

\begin{tabular}{lccc}
\hline & $\begin{array}{c}\text { Unstandardized } \\
\text { Coefficients }\end{array}$ & & $\begin{array}{c}\text { Sig. } \\
\text { Model }\end{array}$ \\
B & T & (One tailed) \\
\hline Constant) & $-1,109$ & $-6,769$ & 0,000 \\
EP & 1,331 & 3,483 & 0,001 \\
LEV & 0,028 & 0,914 & 0,362 \\
SIZE & 0,036 & 5,852 & 0,000 \\
EP_KI & $-0,011$ & $-2,293$ & 0,023 \\
LEV_KI & 0,000 & $-0,627$ & 0,531 \\
SIZE_KI & 0,000 & 0,897 & 0,371 \\
R Square $\left(R^{2}\right)$ & & & 0,351 \\
F $_{\text {hitung }}$ & & & 24,569 \\
Sig. F & & & $0,000^{\mathrm{b}}$ \\
\hline
\end{tabular}

Dependent Variable: ML

Berdasarkan tabel 8 dapat menghasilkan model sebagai berikut:

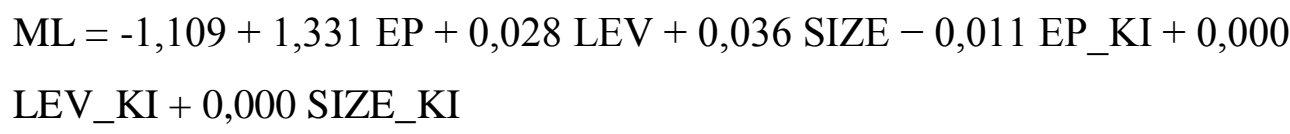

Hasil analisis regresi berganda pada tabel 7 menunjukkan bahwa:

a. Kepemilikan institusional memperlemah hubungan antar earning power terhadap manajemen laba

b. Kepemilikan institusional tidak memoderasi hubungan antar leverage terhadap manajemen laba 
c. Kepemilikan

institusional tidak memoderasi hubungan antar ukuran perusahaan terhadap manajemen laba

\section{Uji Signifikansi Keseluruhan dari} Regresi Sampel (Uji Statistik F)

Hasil pengujian statistik $F$ pada model pertama pada tabel 4.7 diperoleh nilai uji $\mathrm{F}$ sebesar 46,897 dan nilai signifikansi uji $\mathrm{F}$ sebesar $0,000^{\mathrm{b}} \leq 0,05$ artinya model regresi linear pertama signifikan dan layak digunakan untuk mendeteksi manajemen laba atau dengan kata lain bahwa variabel EP, LEV, dan SIZE secara bersama-sama berpengaruh signifikan terhadap ML.

Hasil analisis regresi dengan moderated regression analysis (MRA) pada tabel 8 diperoleh nilai uji signifikansi keseluruhan dari regresi sampel (uji F) dengan nilai 24,569 dan uji $\mathrm{F}$ sebesar $0,000^{\mathrm{b}}$ $\leq 0,05$ artinya model regresi signifikan dan layak untuk digunakan untuk mendeteksi manajemen laba atau dengan kata lain bahwa variabel EP, LEV, SIZE, interaksi EP dan KI, interaksi LEV dan KI, serta interaksi SIZE dan KI secara bersama-sama berpengaruh signifikan terhadap ML.

\section{Uji Ketepatan Perkiraan}

(Goodness of Test atau Koefisien Determinasi)

Hasil pengujian koefisien determinasi dapat dilihat pada tabel 7 di atas yang menampilkan nilai koefisien determinasi ( $\mathrm{R}$ square) model pertama sebesar 0,338 yang berarti sebesar 33,8\% naik turunnya manajemen laba (ML) dipengaruhi oleh earning power (EP), leverage (LEV), dan ukuran perusahaan (SIZE) sedangkan sisanya sebesar $66,2 \%$ dijelaskan oleh variabel lain diluar model regresi yang digunakan.

Untuk model kedua yang dapat dilihat pada tabel 8 , diperoleh nilai koefisien determinasi ( $\mathrm{R}$ square) sebesar 0,351 yang berarti sebesar $35,1 \%$ naik turunnya manajemen laba (ML) dipengaruhi oleh earning power (EP), leverage (LEV), ukuran perusahaan (SIZE), interaksi antara earning power dengan kepemilikan institusional (EP_KI), interaksi antara leverage dengan kepemilikan 
institusional (LEV_KI) dan interaksi antara ukuran perusahaan dengan kepemilikan institusional (SIZE_KI) sedangkan sisanya sebesar $64,9 \%$ dijelaskan oleh variabel lain diluar model regresi yang digunakan.

\section{Uji Signifikansi Parameter} Individual (Uji Statistik t)

Penelitian ini menggunakan $\alpha$ sebesar 5\% dengan nilai t tabel \pm 1,650 dan penelitian ini dilakukan menggunakan satu sisi (one tailed). Berdasarkan tabel 4.7 diatas dapat dilihat bahwa:

(1) Earning power berpengaruh secara parsial terhadap manajemen laba

(2) Leverage berpengaruh secara parsial terhadap manajemen laba

(3) Ukuran perusahaan berpengaruh secara parsial terhadap manajemen laba

\section{Pembahasan}

Penelitian ini ingin membuktikan apakah earning power, leverage, dan ukuran perusahaan berpengaruh terhadap manajemen laba serta apakah kepemilikan institusional memoderasi pengaruh earning power, leverage dan ukuran perusahaan terhadap manajemen laba.

(1) Pengaruh earning power terhadap manajemen laba

Hasil penelitian ini sesuai dan searah dengan penelitian yang dilakukan oleh Surya et al. (2016) yang menyatakan pengaruh earning power berdasarkan ROA terhadap manajemen laba mempunyai hubungan (korelasi) yang erat serta searah atau positif hal ini berarti apabila terjadi kenaikan pada earning power perusahaan akan diikuti dengan kenaikan discretionary accrual, begitu pula sebaliknya jika terjadi penurunan earning power akan terjadi penurunan discretionary accrual pula.

Hal ini disebabkan karena investor beranggapan bahwa earning power yang tinggi akan menjamin pengembalian investasi serta akan memberikan keuntungan yang layak, oleh karena itu perusahaan harus menampilkan kinerja manajemen yang baik sehingga earning power perusahaan dapat dilihat maksimal untuk menarik 
perhatian para investor. Selain itu, jika perusahaan melaporkan laba yang dapat memenuhi atau lebih besar dari laba yang diharapkan oleh investor maka investor akan beranggapan bahwa perusahaan memiliki kinerja yang baik dan manajer perusahaan akan dinilai mampu mengelola perusahaan dengan baik. Oleh karena itu, manajer perusahaan akan terdorong untuk melakukan manajemen laba agar laba perusahaan dapat dipertahankan pada tingkat tertentu sesuai dengan harapan investor, terlebih lagi jika manajer dijanjikan akan memperoleh sejumlah bonus sebagai imbalannya.

Untuk mempertahankan laba pada tingkat tertentu pola yang akan dilakukan oleh manajer adalah pemerataan laba (income smoothing) yaitu pada saat laba perusahaan naik manajer akan merendahkan laba agar jika pada periode dimana laba perusahaan rendah manajer dapat menaikan laba perusahaan agar tetap stabil pada tingkat tertentu. Manajer juga melakukan pemerataan laba (income smoothing) agar selalu mendapatkan bonus (Bonus Scheme) yaitu jika laba sudah melewati tingkat tertentu maka manajer akan mengelola dan mengatur agar laba yang dilaporkan menjadi tidak terlalu tinggi. Kelebihan laba sesungguhnya akan disajikan pada tahun tingkat laba perusahaan berada dibawah syarat untuk menerima bonus.

(2) Pengaruh leverage terhadap manajemen laba

Hasil penelitian ini sesuai dan juga searah dengan penelitian yang dilakukan oleh Safitri (2014) yang menyatakan bahwa semakin tinggi atau rendahnya leverage berpengaruh signifikan terhadap pelaksanaan manajemen laba perusahaan. Hal ini disebabkan oleh karena semakin tinggi hutang perusahaan dibanding dengan modal perusahaan akan mencerminkan risiko yang semakin tinggi pula yang akan dihadapi oleh perusahaan berupa risiko ketidakmampuan membayar kewajiban ataupun 
risiko terjadinya pelanggaran perjanjian hutang.

Leverage yang tinggi

dibandingkan leverage industri pada umumnya akan mengakibatkan suatu perusahaan kesulitan untuk memperoleh dana tambahan dengan melakukan pinjaman. Hal ini dikarenakan kreditur akan menolak meminjamkan uang lebih banyak sebab kreditur memerlukan jaminan atas dana yang dipinjamkan, maka akan sulit bagi perusahaan yang mempunyai leverage tinggi meminjam dana tambahan tanpa menambah ekuitas terlebih dahulu. Perusahaan yang sudah melakukan go public dapat memperluas pencarian dana melalui suntikan dana yang cukup besar dari investor dan kemungkinan kreditur juga akan menambah dana yang dipinjamkan karena resiko kerugian akan ditanggung bersama dengan investor.

Oleh karena itu perusahaan yang sudah melakukan go public akan berlomba-lomba untuk menarik investor untuk menanamkan modalnya pada perusahaannya. Sehingga manajer harus memperlihatkan kinerja manajemen perusahaan yang baik melalui posisi keuangan perusahaan yang baik. Oleh karena itu manajer akan cenderung melakukan pemerataan laba salah satunya dengan cara menunda beban pada periode bersangkutan dan akan diselesaikan pada periodeperiode mendatang agar dapat meningkatkan laba sehingga dapat memberi jaminan kepada para kreditor dan dapat mengurangi risiko-risiko terkait dengan pihak kreditor.

(3) Pengaruh ukuran perusahaan terhadap manajemen laba Hasil penelitian ini tidak searah dengan hipotesis penelitian. Namun hasil tersebut konsisten dan searah dengan penelitian yang dilakukan oleh Ali et al. (2015) yang menyatakan ukuran perusahaan mempunyai hubungan positif dengan manajemen laba. Hal itu dikarenakan perusahaan yang lebih besar menghadapi lebih 
banyak tekanan dari para investor dan analisis keuangan untuk menyajikan penerimaan yang positif atau peningkatan laba. Selain itu perusahaan besar juga memiliki kekuatan tawar menawar untuk melakukan negosiasi dengan para auditor, lebih banyak tindakan yang dapat dilakukan terhadap transaksi yang mereka miliki dan kekuatan manajemen yang lebih kuat yang mereka miliki yang membuat lebih muda untuk memanipulasi laba.

Selain itu perusahaan yang lebih besar juga cenderung memiliki laba yang lebih besar dan harus membayar pajak yang lebih besar sehingga akan membuat manajer mengatur labanya pada jumlah tertentu agar pajak yang harus dibayarkannya menjadi tidak terlalu tinggi, karena manajer tidak ingin kewajiban yang harus diselesaikannya akan membebaninya. Sesuai dengan Political Cost Hypothesis manajer juga bisa mengatur laba pada saat pergantian peraturan perundang-undangan yang memberlakukan tarif pajak lebih rendah untuk menghemat pajak.

(4) Pengaruh kepemilikan institusional dalam memoderasi hubungan antara earning power terhadap manajemen laba Hasil penelitian membuktikan bahwa kepemilikan institusional terbukti memperlemah hubungan positif antara earning power terhadap manajemen laba. Hal ini membuktikan bahwa saat tingkat earning power semakin tinggi maka manajer cenderung melakukan manajemen laba, tetapi dengan adanya keterlibatan pihak institusi pada perusahaan maka manajer akan lebih berhati-hati untuk melakukan manajemen laba. Sehingga dengan adanya kepemilikan institusi maka manajer akan cenderung melaporkan kondisi perusahaan yang sebenarnya/ sesungguhnya.

(5) Pengaruh kepemilikan institusional dalam memoderasi hubungan antara leverage terhadap manajemen laba Hasil penelitian membuktikan bahwa kepemilikan institusional 
tidak cukup bukti memperlemah

hubungan positif antara leverage terhadap manajemen laba. Sehingga dapat disimpulkan bahwa kepemilikan institusional tidak mampu memoderasi (memperkuat atau memperlemah) hubungan antara leverage terhadap manajemen laba. Namun hasil tersebut sesuai dengan penelitian yang dilakukan oleh Naftalia dan Marsono (2013) yang menyatakan kepemilikan institusional terbukti tidak memoderasi pengaruh leverage terhadap manajemen laba. Hal ini terjadi karena pihak institusi yang berperan sebagai pengawas tindakan-tindakan yang dilakukan oleh manajer tidak dapat mengetahui atau mendeteksi risiko-risiko ketidakmampuan membayar kewajiban dan pelanggaran perjanjian kredit yang diketahui oleh manajer karena tingginya tingkat leverage perusahaan.

(6) Pengaruh kepemilikan institusional dalam memoderasi hubungan antara ukuran perusahaan terhadap

manajemen laba

Hasil penelitian membuktikan bahwa kepemilikan institusional tidak cukup bukti memperkuat hubungan negatif antara ukuran perusahaan terhadap manajemen laba. Sehingga dapat disimpulkan bahwa kepemilikan institusional tidak mampu memoderasi (memperkuat atau memperlemah) hubungan antara ukuran perusahaan terhadap manajemen laba. Hal ini disebabkan karena pihak institusi lebih memfokuskan pada current earning. Dengan adanya kepemilikan institusional pada perusahaan besar akan membuat manajer merasa terikat untuk memenuhi target laba dari para investor, sehingga mereka akan tetap cenderung terlibat dalam tindakan manipulasi laba. Karena pihak institusi fokus pada current earnings maka manajer akan terpaksa untuk melakukan tindakan yang dapat meningkatkan laba jangka pendek. Sehingga dengan adanya kepemilikan institusional dalam perusahaan besar tidak 
akan meminimalisir tindakan manajemen laba.

\section{KESIMPULAN}

Berdasarkan hasil penelitian yang telah dilakukan, maka peneliti menarik beberapa kesimpulan sebagai berikut :

1. Earning power berpengaruh positif terhadap manajemen laba.

2. Leverage berpengaruh positif terhadap manajemen laba.

3. Ukuran perusahaan tidak cukup bukti berpengaruh negatif terhadap manajemen laba.

4. Kepemilikan institusional memperlemah hubungan antara earning power terhadap manajemen laba.

5. Kepemilikan institusional tidak cukup bukti memperlemah hubungan antara leverage terhadap manajemen laba.

6. Kepemilikan institusional tidak cukup bukti memperkuat hubungan antara ukuran perusahaan terhadap manajemen laba.

\section{Saran}

Berdasarkan hasil pembahasan dan simpulan yang telah diuraikan maka saran dan peluang bagi peneliti selanjutnya yakni sebagai berikut:

1. Penelitian ini menggunakan data seperti laba/rugi dan kepemilikan institusional perusahaan secara menyeluruh. Peneliti selanjutnya diharapkan menentukan motivasi dan pola manajemen laba yang akan diteliti dan juga menggunakan data persentase kepemilikan institusional yang memiliki hak untuk mengawasi agar penelitian lebih terarah dan hasil penelitian akan lebih bermanfaat.

2. Peneliti selanjutnya juga diharapkan memperpanjang periode pengamatan untuk melihat konsistensi hasil penelitian. Penelitian selanjutnya juga diharapkan dapat menambahkan atau memasukkan variabel lain selain variabel-variabel yang diuji pada penelitian ini, seperti good corporate 


$$
\begin{aligned}
& \text { governance, pertumbuhan } \\
& \text { perusahaan, } \\
& \text { perusahaan, dan sebagainya. }
\end{aligned}
$$

\section{DAFTAR PUSTAKA}

Alhavid (2009). Pengaruh Earning Power dan Good Corporate Governance Terhadap Manajemen Laba, E-Journal Universitas Negeri Padang, diakses 24 Juni 2017, http://ejournal.unp.ac.id/stu dents/index.php/akt/ article/view/1638/1261

Ali, Usman et al. (2015). Impact of Firm Size on Earnings Management; A Study of Textile Sector of Pakistan, European Journal of Business and Management, Vol. 7, No. 28, 47-56

Alves, Sandra (2012). Ownership Structure and Earnings Manegement: Evidence from Portugal, Australasian Accounting Business and Finance Journal, Vol. 6, No. $1,57-74$

Belkaoui and Ahmed Riahi (2004). Accounting Theory, Edisi 5, United States of America: Thomson

Bowerman, et al. (2014). Business Statistiks in Practice Seventh Edition, United States: McGraw - Hill International Edition.
Chandra, Tracy V. dan Yustina Triyani (2013). Pengaruh Mekanisme Corporate Governance dan Ukuran Kantor Akuntan Publik Terhadap Manajemen Laba Pada Perusahaan Industri Manufaktur yang Terdaftar di Bursa Efek Indonesia Periode 2009-2011, Vol.2, No. 2, 161-188

Cooper, Donald R., Pamela S. Schindler (2017). Metodologi Penelitian Bisnis, Edisi Kedua Belas, Buku 1, Terjemahan oleh Rahma Wijayanti, Gina Gania, Jakarta, Penerbit Salemba Empat.

Cornett, Marcia M., et al. (2006). Earning Management, Corporate Governance, and True Financial Performance. Diakses 10 Mei 2017, http://papers.ssrn.com/

Eisenhardt, Kathleen M. (1989). Agency Theory: An Assessment and Review, Academy of Management, vol. 14, No. 1, 57-74

Elfira, Anisa (2014). Pengaruh Kompensasi Bonus dan Leverage Terhadap Manajemen Laba, E-Journal Universitas Negeri Padang, diakses 24 Juni 2017, http://ejournal.unp.ac.id/stu dents/index.php/akt/article/v iew/1053 
Ghozali, Imam (2016). Aplikasi Analisis Multivariate dengan Program IBM SPSS 23, Semarang: Badan Penerbit Universitas Diponegoro.

Gitman, Lawrence. J., Chad J. Zutter (2015). Principles of Managerial Finance fourteenth edition, Global Edition, United States Edition: Pearson.

Hakim, Ifsan L. (2015). Skandal Terungkap, CEO Toshiba Mundur, Bisnis Liputan6, diakses 18 Mei 2017, http://bisnis.liputan6.com/re ad/ 2277114/skandalterungkap-ceo-toshibamundur

Handayani, RR. S., dan Agustono Dwi Rachadi (2009). Pengaruh Ukuran Perusahaan Terhadap Manajemen Laba, Jurnal Bisnis dan Akuntansi, Vol. 11, No. 1, 33-56

Healy, Paul M. and J. M. Wahlen (1999). A Review of the Earnings Management Literature and Its Implications for Standard Setting. Accounting Horizons, December, 365383
I Guna, Welvin dan Arleen Herawaty (2010). Pengaruh Mekanisme Good Corporate Governance, Independensi Auditor, Kualitas Audit dan Faktor Lainnya Terhadap Manajemen Laba, Jurnal Bisnis dan Akuntansi, Vol. 12, No. 1, 53-68

Isenmila, P. A., and Afensimi Elijah (2012). Earnings

Management and Ownership Structure: Evidence from Nigeria, Research Journal of Finance and Accounting, Vol. 3, No. 7, 24-36

Jensen, Michael C and K. J. Murphy (1990). Performance Pay and Top-Management Incentives. Journal of Political Economy, Vol. 98, No. 2, 225-264

Jensen, Michael C. and W. H. Meckling (1976). Theory of The Firm : Managerial Behavior, Agency Cost and Ownership Structure. Journal of Financial Economics, October, Vol 3, No. 4, hal : 305-360

Jones, Jennifer J. (1991). Earnings Management During Import Relief Investigations. Journal of Accounting Research, Vol. 29, No. 2, 193-228 
Kamran and Attaullah Shah (2014).

The Impact of Corporate Governance and Ownership Structure on Earnings Management Practices: Evidence from Listed Companies in Pakistan, The Lahore Journal of Economics, Vol. 19, No. 2, 27-70

Naftalia, Veliandina C., dan Marsono (2013). Pengaruh Leverage Terhadap Manajemen Laba dengan Corporate Governance Sebagai Variabel Pemoderasi, Diponegoro Journal of Accounting, Vol. 2, No. 3, $1-8$

Purnomo, Budi S., dan Puji Pratiwi (2009). Pengaruh Earning Power Terhadap Praktek Manajemen Laba (Earning Management), Jurnal Media Ekonomi, vol. 14, No. 1

Riyanto, Bambang (2008). DasarDasar Pembelanjaan Perusahaan, Edisi 4, Yogyakarta: Yayasan Badan Penerbit Gadjah Mada

Savitri, Enni (2014). Analisis Pengaruh Leverage dan Siklus Hidup Terhadap Manajemen Laba Pada Perusahaan Real Estate dan Property yang Terdaftar di Bursa Efek Indonesia, Jurnal Akuntansi, Vol. 3, No. $1,72-89$

Scott, William R. (2015). Financial Accounting Theory, Edisi 7, United States of America: Pearson.
Sugiyono (2012). Metode Penelitian Bisnis, Bandung: Alfabeta.

Suhendra (2015). BEI: Laporan Keuangan Inovisi Salah Saji, Suspen Saham Belum Akan Dibuka, Bareksa, diakses 28 Mei 2017, http://www.bareksa.com /id/text/2015/02/25/beilaporan-keuangan-inovisisalah-saji-suspen-sahambelum-akandibuka/9562/analysis

Sulistyanto, H. Sri (2014). Manajemen Laba, Teori dan Model Empiris, Jakarta: Grasindo

Surya et al. (2016). Pengaruh Earning Power Terhadap Earning Management, Jurnal Ilmu Akuntansi, vol. 9, 97-115

Suwardjono (2005). Teori Akuntansi: Pengungkapan dan Sarana Interpretatif, Edisi 3, BPFE, Yogyakarta

Ujiyantho, M. A., dan Bambang Agus Pramuka (2007). Mekanisme Corporate Governance, Manajemen Laba dan Kinerja Keuangan, Simposium Nasional Akuntansi X, Unhas Makassar 26-28 Juli 2007

Watts, Ross L. and Jerold L. Zimmerman (1986). Positive Accounting Theory, Edisi 1, New Jersey: Prentice-Hall, Inc. 
Widyaningdyah, Agnes U. (2001). Analisis Faktor-Faktor yang Berpengaruh Terhadap Earning Management pada Perusahaan Go Public Di Indonesia, Jurnal Akuntansi \& Keuangan, Vol. 3, No. 2, 89-101
Yang, Wong Shi et al. (2009). The Effect of Board Structure and Institutional Ownership Structure on Earnings Management, Int. Journal of Economics and Management, Vol. 3, No. 2, 332-353 